\title{
7
}

\section{Cross-Cutting Issues, Challenges, Good Practices and Possible Intervention Opportunities}

\subsection{Introduction and Overview}

The objective of this final chapter is to summarise the main findings from this research and highlight the most important lessons in the analysis of decentralisation policy in these five countries. We start with a presentation of the profile of the five countries. We then proceed to analyse the current decentralisation policies and practices in terms of performance, policy and institutional choices, and finally highlight the lessons and challenges and identify possible good practice and intervention points by national governments and other interested stakeholders.

\subsubsection{Profile of the case study countries}

Table 7.1 shows that of the five countries, Tanzania is the most highly and densely populated, followed by Ghana and Mozambique in terms of total population, but in terms of density Ghana has by far the highest density. Botswana is the smallest and the least populated but also the most economically prosperous, having a GDP of US $\$ 13,100$ and international poverty level of only 35 per cent. This contrasts with Tanzania, which has the highest poverty level (97 per cent) and Mozambique and Tanzania with the lowest per capita incomes. Perhaps the most important indicator in Table 7.1 is the infant mortality rate (IMR). This is the one indicator that local administrations and local governments can influence. They are charged with responsibility for basic health in most countries of the world (Shah, 2006). Of the five countries, Mozambique has the highest IMR followed by Cameroon and Tanzania. Botswana, followed by Ghana, have the lowest IMRs. Whether this is the outcome of effective national or local institutional action is explained in this final chapter.

It is instructive to note that all five countries, despite their varying geographic and demographic sizes, have adopted unitary and multiparty democracy as their systems of governance. It is equally noteworthy that both Cameroon and Tanzania had reverted to unitary systems of government by the time of this research, though they had adopted federal systems earlier on. 
Table 7.1. Summary of country profiles showing similarities and differences

\begin{tabular}{llllll}
\hline Country profile & Botswana & Cameroon & Mozambique & Tanzania & Ghana \\
\hline Population (2009 estimate) & $1.9 \mathrm{~m}$ & $18.9 \mathrm{~m}$ & $21.7 \mathrm{~m}$ & $43.7 \mathrm{~m}$ & $23.8 \mathrm{~m}$ \\
Population density (per km2) & 3 & 40 & 26.8 & 46 & 100 \\
Type of state & Unitary & Unitary & Unitary & Unitary & Unitary \\
Tiers of government & 2 & 3 & 3 & 3 & 3 \\
Number of central government ministries & 15 & 33 & 24 & 23 & 23 \\
Multi-party democracy & Yes & Yes & Yes & Yes & Yes \\
GDP - per capita (PPP, US $\$$ in 2008) & 13,100 & 2,180 & 770 & 1,230 & 1,430 \\
National poverty level & $30 \%$ & $22.1 \%$ & $51.5 \%$ & $29.5 \%$ & $28.5 \%$ \\
& $(2003)$ & $(2001)$ & & $(2003)$ & $(2006)$ \\
\% population below international poverty & $35 \%$ & $58 \%$ & $90 \%$ & $97 \%$ & $54 \%$ \\
line (US 2 (2008) & & & & & \\
Infant mortality rate/1,000 & 48 & 74 & 97 & 69 & 50 \\
Life expectancy & 49 & 52 & 43 & 54 & 59 \\
\hline
\end{tabular}

Various sources, including http://data.un.org/CountryProfile and Population Reference Bureau, 2009.

We will now proceed to analyse in summary form the current state of decentralisation in these five countries.

\subsection{Analyses of Current Decentralisation Policies and Practices}

Decentralisation policies have received renewed impetus in all five countries. Several factors explain this renewed interest. When most of the countries approached independence in the 1960s, state/nation building was the primary consideration and the clear preference of most countries in the region was for a stronger system of local government or devolution to match their preference for popular democracy at the national level. After about a decade, most of the countries in the region shelved their democratic pretences at the national level and adopted more autocratic models of governance. Inevitably, stronger systems of field administration or deconcentration became the prevailing policy preference. ${ }^{1}$ In the 1980 s and 1990 s economic and political reforms as well as the forces of globalisation that encouraged the free movement of capital and labour from the industrial countries of the west to the developing and transitional countries led the drive for a different kind of decentralisation: devolution. At the turn of the century, nations of the world refocused their energies on the MDGs and drastically reducing global poverty (by one half by 2015). In this context, nations began to review their decentralisation policy choice. While some became convinced that these forces pointed to the need to enhance systems of devolution, others were convinced that conflicts, corruption, co-ordination, costs 
and capacity issues could complicate efforts at implementing devolutionary decentralisation. This is the context in which the present evaluation was conducted by the Commonwealth Secretariat in collaboration with the five pre-selected countries. In this final chapter, we review the main findings, discuss their implications, and highlight some important lessons. We start with the choices made in respect of key service sectors - basic health, education, health, water and sanitation.

\subsubsection{Sectoral decentralisation: institutional and policy choices}

In the five countries attempts have been made to decongest line ministries such as education, health, water and sanitation, land, agriculture, etc. The question is what has happened to the services that are regarded in each country's policies as 'local' and which are universally delivered by local authorities, namely basic education, basic health, sanitation, etc. within the context of national deconcentration? In other words, what kinds of field administration arrangements are being used in each country and what is the balance between deconcentration and devolution in the delivery of these services? Table 7.2 summarises our findings.

In Botswana, all line ministries have established deconcentrated district offices to implement projects directly at the community level. The activities of sectoral field officers are co-ordinated by the district commissioner who is appointed by the president, but given that this 'sub-prefect' has little administrative power over sectoral field officers, most of the employees report directly to their parent ministries in Gaborone and have minimal allegiance to the district administration. In education, district councils provide primary school infrastructure and maintenance while the Ministry of Education provides teaching, curricula, supervision and management. In health services, all of the 525 PHCs have been devolved to local councils whereby the councils build the infrastructure, employ the staff and manage health care services. The $\mathrm{MoH}$ is responsible for hospitals and health centres. Water provision is shared between three institutions. Rural water is the responsibility of district councils; urban water is the responsibility of the Water Utility Corporation (a parastatal), while major villages' water supply is the responsibility of the Department of Water Affairs at the Ministry of Minerals, Energy and Water Resources (MMEWR). In terms of solid waste collection most of the urban councils and a few rural ones have combined two modalities for their delivery: contracting out to private enterprises and direct delivery using the council's own employees and equipment. However, the Department of Water Affairs of the MMEWR delivers capital sanitation systems for urban areas.

In Cameroon, public service delivery is handled by sector ministries. A proposed new framework for service delivery under the decentralisation programme decreed that the delivery of social services be transferred gradually from sector ministries to local councils over a five-year period spanning 2010-2014. This law promises to transfer competencies in the areas of agriculture and rural development, public transport, education, energy and water, and health. 
In Ghana, basic education and health are delivered by specialised agencies. (Parastatal organisations and local authorities are only tangentially involved, even though the law assigns these responsibilities to them.) Water and sanitation, on the other hand, has been privatised and either central or local governments have contracted private organisations as a part of government policy.

In Mozambique sectoral deconcentration as part of the broader public sector reforms that started in 1998 resulted in ministries allowing the provincial governments to undertake planning, budgeting, implementation and management. For instance in the education sector policies, strategic plans, curriculum development and teacher training remained with the MoE while infrastructure development, hiring teachers, paying salaries, etc. is the responsibility of provincial government. Although primary health care and education are supposed to be devolved to municipal government, in Mozambique they are still being managed by the sectoral government ministries. The $\mathrm{MoH}$ is one line ministry that resists deconcentration. The $\mathrm{MoH}$ has totally replicated its organisational structure at the provincial level and instituted strict control over the provincial health directorate. The outcome of sectoral deconcentration in Mozambique is that much of the recurrent budget is spent at the provincial government level. For instance, in the education sector, about 80 per cent of recurrent expenditures are at the provincial level, making education the most deconcentrated sector. On the other hand, the degree of deconcentration of recurrent expenditures is much lower in the other 'deconcentrated sectors' such as agriculture, public works and health. In each of these sectors, only 40-50 per cent of expenditure is deconcentrated. More than 80 per cent of all capital expenditure in all sectors takes place at the ministry level.

In Tanzania, primary education delivery is devolved in principle, however the Teaching Service Commission, a central government parastatal, recruits teachers. School management committees now manage a substantial part of the budget and it is significant that only the education sector has registered major service delivery achievements to date. These achievements have been mostly quantitative (increased enrolment, etc.) and are primarily explained by the sector's strong policy focus (universal primary education) and increased public budgets. In the breakdown of conditional allocation for LG administration, education accounts for some 70 per cent of allocations, health 18 per cent, administration 6 per cent and water, roads and agriculture together 6 per cent. The $\mathrm{MoH}$ introduced reforms with a strategy to devolve administration and management of health services to local authorities by introducing Council Health Services Boards and various Health Facility Committees that work under the LGs. The aim is to increase community participation in the planning and management of the health sector. In implementation, boards and committees have a mixed membership with government, voluntary agencies, private for-profit health providers and community representation. 
Table 7.2. Sectoral decentralisation practices

\begin{tabular}{|c|c|c|c|}
\hline & Basic education & Basic health & Water and sanitation \\
\hline Botswana & Deconcentration & $\begin{array}{l}\text { Devolved but moving in direction } \\
\text { of deconcentration or agency }\end{array}$ & $\begin{array}{l}\text { Deconcentration/ } \\
\text { agency }\end{array}$ \\
\hline Cameroon & Deconcentration & Deconcentration & Deconcentration \\
\hline Ghana & Deconcentration & Deconcentration & $\begin{array}{l}\text { Agencification/ } \\
\text { privatisation }\end{array}$ \\
\hline Mozambique & Deconcentration & Deconcentration/centralisation & Deconcentration \\
\hline Tanzania & Devolved-except teachers & Devolved & Devolved \\
\hline
\end{tabular}

Source: Qualitative analysis of Country Reports submitted to Commonwealth Secretariat, 2009

Table 7.2 summarises the sectoral decentralisation practices for each country in three service areas. It shows that across the five countries by late 2009 (when field studies were conducted in these countries), the degree of variation in sectoral decentralisation practices range from almost near full devolution in Tanzania, to a mix of devolution and deconcentration in Botswana and Mozambique, to deconcentration in Ghana (with a few cases of agencification) and Cameroon. Both Mozambique and Botswana are moving away from devolution towards deconcentration and in the direction of deconcentration/agencification and centralisation with respect to health care management.

The above institutional choices have had varying impact on the performance of each of the services mentioned in the five countries.

\subsubsection{Political decentralisation}

In this section, we examine local democratic institutions in the five countries by highlighting the conditions under which local leaders and councillors are appointed, patterns of electoral competition, voter turnout, autonomy of local leaders to make decisions and laws, etc. The objective of these institutional devices or mechanisms is to improve the quality of accountable management through local-level institutions. This section therefore focuses on indicators of political leadership recruitment and citizen participation as judged by local elections.

Political leadership: Every political system must have a system of leadership recruitment. Devolution offers a system for recruiting political leaders and training both leaders as well as citizens in the local political arena, in preparation for the national level.

There are four main methods of leadership selection in local governments generally. These are the weak and strong mayor systems, the council/city manager, or the commission plan. Each of these has its strengths and weaknesses. In the five countries, the weak mayor system is dominant. Here, elected local councillors 
elect the chairperson and can remove him/her by a vote of no confidence. Each department of the council is run by a committee of the whole council. This system was inherited by most former British colonies, and even though the system has been radically transformed in the UK towards an executive model, most English-speaking former colonies still use the weak mayor system. The strength of the system is that it involves all councillors in the management of the council. On the other hand, co-ordination is also weak as there is really no focal point for local governance. In Africa, an additional challenge is the fact that national partisan politics dominates local council administration. Moreover, the system makes it easy for councillors to put pressure on the (weak) mayor to meet personal and at times corrupt demands by the councillors or their constituents (Olowu, 2005).

For these reasons, the research shows that most countries are interested in experimenting with the 'strong mayor' system. Only Mozambique uses this model among the five case study countries. Ghana uses a combination of the weak mayor model and a modified (colonial) district executive officer model. The main modification is that there are two main leaders at the district level - the elected mayor who is effectively a weak mayor, complimented by a chief executive officer who is a presidential appointee. Each person proposed must be approved by the council leadership and he/she can be replaced or removed based on an appeal from the councillors to the president.

Local elections: All countries hold local elections to determine local political leaders. Botswana has devolved politics to the local level and people have the right to elect their councillors every five years. Local elections are held at the same time as national parliamentary elections but information on local-level election turnout was not available. Officials assured the research team that there was no significant difference between voter turnout in local and national elections, although there was no way to independently verify this. For national elections average voter turnout has not gone below 75 per cent of registered voters since 1989 (76.6 per cent in 1994; 77.1 per cent in 1999; 76.2 per cent in 2004; and 75.2 per cent in 2009). In addition, the central government appoints a few councillors to the local councils. Although the ruling BDP enjoys massive support across the country, it had been losing seats to the opposition in many urban and town councils until 2009. Gaborone City Council, for example, was held by the opposition for 22 years until the ruling BDP took control in 2009. The ruling party has become more dominant in national and local elections, although voter turnout ${ }^{2}$ for national elections has been falling, whereas it has been rising for local elections since 1994.

LG Act 40:01 (section 33) gives district councils the authority to make byelaws in respect of all matters as they consider necessary for the maintenance of the health, safety and well-being of the inhabitants of their area. Councillors receive monthly salaries for the services they render and a seating allowance anytime they meet to deliberate and take decisions on LG issues. 
In Mozambique only municipal residents (about one-third of the population) have the right to elect their local councillors and mayors. Since 1998 (when the first municipal government election took place) there have been two additional elections for five-year mandates. However, both national and municipal elections are dominated by the ruling FRELIMO party. Government officials attribute low turnout in municipal elections to people's disinterest in local politics. Another reason given by those outside government is that people think their vote would not change anything since there is no credible opposition party to compete with FRELIMO. But it is important to note that - as in Botswana - while voter turnout is increasing at municipal elections (from 15 per cent in 1998 to 46 per cent in 2008) the opposite is taking place at national elections. Voter turnout at national elections has declined from 87 per cent in 1994 to 44 per cent in 2009. It significant to note that the Mozambican (strong) mayor has the power to employ, pay and fire other administrative staff in the municipality management structure. The municipal assembly, which is the local legislature, approves the municipal plan and budget and authorises the expenditure of the executive. Since 2008 councillors have received monthly salaries instead of seating allowances. The LG finance law requires municipalities to use 40 per cent of their internally generated revenue to pay local politicians (councillors and mayors).

In Cameroon elections to local councillor positions are held at five-year intervals, and councillors appoint from within their ranks mayors who will head the respective local jurisdictions (weak mayor system). However, these mayors have to work with government appointees who serve as secretary-generals in the councils. Although the latter's role is supposed to be advisory, information obtained during interviews shows that it is common for secretary-generals to assume control of council operations much closer to the Ghanaian model. Moreover, these officials are actually control the councils in respect of programmes and public services delivered. As in Botswana, we were not able to obtain voter turnout rates for local or municipal elections exclusively, but we understand that voter turnout at national elections increased from 60.6 per cent in 1992 to 75.6 per cent in 1997, and 82.2 per cent in 2004 (Kuenzi and Lambright, 2007; Touo, 2009). This is different from all the other countries in our sample, where participation in national elections has declined from 70.1 to 56 per cent between 1999 and 2003 in Botswana, 88 to 68 per cent between 1994 and 1999 in Mozambique, and from 76.5 per cent in 1995 to 72.5 per cent between 1995 and 2005 in Tanzania (Kuenzi and Lambright, 2007).

In Ghana, the district assembly (DA) is the highest legislative and decision-making body at the local level, and consists of a district chief executive (DCE) (who is appointed to represent central government in the district), members directly elected by universal adult suffrage (two-thirds of the DA), the member(s) of parliament (MP) within the district, and members appointed by the president in consultation with chiefs and interest groups in the district (one-third of members). The heads of decentralised 
departments take part in the assembly deliberations to provide technical or expert advice but do not vote.

The day-to-day management of the DAs and implementation of assembly resolutions is the responsibility of the executive committee. Voter interest in DA elections has waned over the years. While the first DA elections produced 59 per cent turnout, subsequent elections have not moved beyond 45 per cent $(29.3$ per cent in $1994,41.6$ per cent in 1998, 32.8 per cent in 2002 and 44 per cent in 2006).

In Tanzania, the number of registered voters and number of votes cast indicates increased local interest and participation. In the period 1995-2005 voter turnout rose from 47.9 per cent to 65.2 per cent even though political power remained centralised in the ruling CCM party. In early 2000, there were 17 fully registered political parties but the CCM dominated parliamentary and local elections. In the 2005 presidential and parliamentary elections the CCM won 206 out of 232 contested seats, 93 per cent of 2,519 wards in the LG elections, and in the 2004 village council elections the CCM won 97 per cent of all votes, up from 95 per cent in the 1999 elections (Tidemand and Msani, 2008; African Elections Database, no date). In the Tanzanian LG structure, government-appointed municipal and district directors and elected politicians share power, although this may vary depending on the activity.

Most of the countries studied have also created opportunities for marginalised groups to get involved in LGs. Tanzania has a quota for women, which has been effective in bringing quality into the local government system. Similar quotas in Ghana and Mozambique have not worked as well, but Ghana has mechanisms for co-opting professionals, traditional chiefs and national-level politicians onto district assemblies.

Table 7.3. Degree of political decentralisation

\begin{tabular}{|c|c|c|c|c|c|}
\hline Political decentralisation & Botswana & Cameroon & Mozambique & Ghana & Tanzania \\
\hline Mayor system & Weak & Weak & Strong & $\begin{array}{l}\text { Bureaucratic } \\
\text { leadership }\end{array}$ & Weak \\
\hline LG voter turnout & Above $75 \% *$ & n.a & $46 \%$ & $44 \%$ & $65 \% *$ \\
\hline $\begin{array}{l}\text { Competitiveness of local } \\
\text { elections }\end{array}$ & High & Moderate & Low & Low & High \\
\hline Autonomy of LG leadership & Low & Low & High & Low & Low \\
\hline $\begin{array}{l}\text { Degree of popular } \\
\text { participation in local } \\
\text { council elections? }\end{array}$ & $\begin{array}{l}\text { High but } \\
\text { declining }\end{array}$ & Moderate & $\begin{array}{l}\text { Low but } \\
\text { increasing }\end{array}$ & $\begin{array}{l}\text { Low } \\
\text { declining from } \\
\text { about } 60 \%\end{array}$ & Moderate \\
\hline $\begin{array}{l}\text { Power to make byelaws } \\
\text { without much interference } \\
\text { from central government }\end{array}$ & Moderate & Moderate & Moderate & Moderate & Moderate \\
\hline
\end{tabular}

* National election figures. Local election figures were not available. 


\subsubsection{Central-local fiscal relationship}

LGs in both developed and developing countries generally depend on central government to finance their expenditure needs, but poor local revenue generation is typical of many African countries. This review of central-local fiscal relationship is based on eight broad indicators: size of central-local government transfers (and whether transfers are automatic, transparent, reliable or not); existence or not of transparent grant-sharing formulas; existence or not of an independent body on IG transfers; ability of LGs to fix their own revenue rates; and proportion of LG internally generated revenue to the budget. The other indices included: size of local government expenditure compared to state/national expenditure, clarity in expenditure assignment between central government and LGs and between different types of local organisations; and authority of LGs to borrow from the private sector.

In Botswana, urban councils depend on central government for about 80 per cent of their recurrent budget, while rural district councils are even more dependent (97 per cent). The internally generated revenue (IGR) sources for local councils are property rates, interest on deposits and rate arrears, rents on council properties, levies on services delivery, etc. Councils have lost traditional sources of income such as land rent to the Land Boards. Urban councils have the potential to generate more from their revenue sources but they are not able because they do not have the authority to set economic rates for most of the services they render to households. For instance, property tax, which is the main source of revenue for urban councils, is fixed by the MoLG in Gaborone, as is the rent that occupants of council houses pay.

Local councils do not make much effort to collect the fees and levies that they have set because they could happily rely on their central government grant instead. In terms of development budget (water, schools, clinics, health posts, roads), all LGs receive a 100 per cent grant from the central government. However, there is neither a law that requires the central government to transfer a specific amount or percentage of the national revenue to LGs nor is there a formula to allocate the grants to districts. In the absence of any formula or criteria, grants for recurrent and development budgets are distributed to councils based on the budget estimates that each council submits and the discretion exercised by the ministries of LG and finance. This creates horizontal inequality between the councils in the distribution of grants. For example, per capita recurrent grants for the six urban councils show a lot of disparity, from as low as P1,231 (US\$180) in Gaborone to P13,315 (US\$1,944) per person in Sowa Township - which many would justify because Gaborone has greater opportunities to mobilise resources within its jurisdiction.

All recurrent and development budgets that the central government transfers to LGs are embedded in the general budget of the MoLG, who also disburses the grants - and therefore the ministry uses that conduit to influence very much how the grants are used. Even where projects have been approved, every subsequent release of funds for 
payments requires permission and approval by the Ministries of both LG and Finance. The LG Act gives local councils in Botswana the power to raise loans of any amount as long as the LG minister is acting in accordance with the advice of the Ministry of Finance and Development Planning. The loans are secured on the revenue and assets of the council. However, borrowing is not common among the councils because the LGs are not short of money. In fact, councils have bank deposits on which they earn substantial interest, making it the second largest source of internally generated revenue (IGR) for urban councils. Monthly and quarterly reports from the councils form the basis of LG accountability to central government on the use of grants. While councils have their own internal auditors, the central government's auditor general also reviews the accounts of district councils yearly (although there is a backlog of at least two years). Although the calibre of council treasurers has improved, it is still a major source of worry to the MoLG and the main reason they give for not transferring all the grants due councils.

In Mozambique, LG laws give powers to municipalities to generate local revenue in order to finance the expenditure and investments responsibilities that have been decentralised to them. The municipalities are given the authority to collect property tax, poll tax, and revenue from markets and advertisements (billboards). With the exception of Maputo, the municipalities' internally generated revenue is about 7-15 per cent of their total revenue budget. Mozambican cities pay little attention to local revenue mobilisation. IGR comes from market fees and small business taxes. Many municipalities do not collect taxes on properties such as land and houses because they do not have the capacity to do so nor do they have data on the value or size of private properties. Therefore, central government fiscal transfers constitute the most crucial part of municipal revenue. The 1997 financial law 11/97 decrees that 3 per cent of the national budget is to be transferred to municipalities. But this financial law was amended in 2008 (Law 1/2008) to reduce the transfer to 1.5 per cent of the national budget. In reality only 1 per cent or less is transferred. Municipal spending as a percentage of total public-sector spending actually shows a slight decrease from 1.03 per cent in 2003 to 0.78 per cent in 2007.

The fiscal transfers are disbursed in two forms: the Municipal Compensation Fund (FCA) and the Investment Fund for Municipal Initiatives (FIIA). The FCA is a non-earmarked grant that municipalities can use to finance recurrent expenditure. The FIIA is for financing capital expenditure and municipalities have full discretion to identify the initiatives to be funded with these resources. In 2008, a formula to distribute central government transfers to municipalities was introduced that takes into consideration population and physical size of the area, but no independent body exists to determine how the grant is distributed. How these are factored into the calculation is also unclear, not only to the municipalities but also to senior civil servants in the ministries of state administration. Only the MoF is responsible for this calculation. The Municipal Finance Law also allows municipalities to borrow 
money from commercial banks within the country, but they would require MoF permission to source commercial funds from outside Mozambique. Apart from government grants, municipalities in Mozambique receive substantial foreign aid. For instance, the total budget of Maputo Municipality in 2009 was about US $\$ 50$ million, of which about 52 per cent comes from foreign aid. At deconcentrated levels, the central government allocates funds to the district administration to support incomegeneration and job-creation projects. In 2006 and 2007, each district administration was given MTn7 million (approximately US $\$ 300,000$ ) by central government. There is no clear methodology for allocating these financial resources among districts. Each district receives roughly the same amount regardless of differences in the size of their population and cost of living. Decisions on the use of the funds rests with the districts' consultative councils. Other resources find their way indirectly to the district councils from the central government budget through parallel ministerial mechanisms (which may or may not provide districts and municipalities with some discretion over use of these resources).

In Cameroon, up until 2009 funds available to councils included general allocation, frontier, and natural disaster allowances (approximately $€ 300,000$ a year per affected council), and forest royalties accruing to timber-producing councils (with the state receiving 50 per cent, timber councils 40 per cent, and timber communities 10 per cent). In the deconcentrated arrangement, councils receive funds based on individual budget requirements. Regarding the general allocation, there is no clear-cut rule as to the proportion of money transferred to sub-national tiers of government from general allocation. The funds that councils receive depend on the budget requests that they each present annually. However with fiscal decentralisation slated to take off in January 2010, a number of laws were put in place in 2009 to facilitate transparent and predictable transfers when the laws come into force. In general, the upper benchmark for Council taxation is CFAfr 100,000; any activity or business that generates more than CFAfr 100,000 (US $\$ 155$ ) is taxed by central government. The relatively non-transparent nature of how intergovernmental grants are allocated and transferred does not make it easy to have a national overview of contributions of transfers, internally generated revenues and loans to the national economy.

In Ghana, as the revenue assignments have not been commensurate with the expenditure assignments, the National Constitution (section 252(1)) of 1989 mandated that the national parliament make provision for the allocation of not less than 5 per cent of total national revenues to the DAs for development. In 1993 the District Assemblies' Common Fund (DACF) (Act 455) was enacted and an independent body was established to administer the fund among the 110 districts. In 2008 the NPP government increased the fund from 5 per cent to 7.5 per cent. DACF is distributed among all the LGs on the basis of a five-factor formula approved by parliament in 1994: equality (based on population per district); needs (based on accessibility to health, education, water, and tarred road services); responsiveness (based 
on a district's effort to generate its internal revenue); service pressure (population density); and reserve. The weights accorded each indicator have varied, with the aim of improving equity. For example in 2008, 'equality' was weighted 50 per cent, 'needs' 40 per cent, 'responsiveness' 5 per cent, and 'service pressure' 5 per cent. Fifteen per cent of the fund was reserved by the common fund administrator to be shared among members of parliament (6 per cent), regional co-ordinating councils ( 1.5 per cent), Ministry of LG-authorised projects (2 per cent), Administration of Common Fund ( 0.5 per cent) and the Government of Ghana's contribution to the District Development Facility (5 per cent). ${ }^{3}$ LGs have no discretion in the use of the fund, but the Common Fund continues to be the most important source of money to finance LG activities in Ghana. It accounts for about 60-75 per cent of metropolitan government revenue, about 70-80 per cent of municipal revenue, and 85-95 per cent of district government revenue. In the poorer three Northern regions of Ghana, the Common Fund accounts for about 90-96 per cent of LG revenue (with the exception of Tamale Metropolitan Assembly).

In mainland Tanzania, LG authorities are responsible for delivering three types of public services: concurrent functions (in five grant-supported sectors - primary education, local health services, agriculture extension, water supply and road maintenance); exclusive local functions (refuse collection); and delegated functions. Approximately two-thirds of local spending is for recurrent purposes, of which about two-thirds is spent on personal emoluments. Intergovernmental transfers fund about 90 per cent of all LG spending, own source revenues account for nearly 10 per cent, while local borrowing is negligible at 0.1 per cent (PMO-RALG, 2008). In 2001/2002 the aggregate revenue for LG was TSh251.8 billion (US\$282 million); this has risen to US\$648 million in 2007/08. Most of the councils depend on intergovernmental transfers to fund their activities, yet only 22 per cent of funds needed for effective and efficient service delivery actually get to LGs. LGAs could earn the right to greater autonomy for development grants, through the LG Capital Development Grant (LGCDG) system. This system provides discretionary capital development grants to LGAs on a formula basis, but only where they have met minimum performance criteria (including financial management) and some governance-related minimum conditions. Development and financing of the system was supported by the World Bank's LG Support Programme and a consortium of development partners. Local authorities can also raise revenue locally through fees charged for taxi registration, bus stands, forestry products, valuation, scaffolding, inoculation and ambulances, licences (road and liquor), property taxes and rents, charges for refuse collection, hire of vehicles, and markets, fines, sales of assets and the recovery of public funds. But generally speaking, the revenue base of local authorities is weak. Councils are supposed to charge only in areas where they provide services. Councils do engage the services of internal auditors, but external auditors are also stationed at regional levels and answer to the national office. 
In sum, with the exception of one country (Cameroon), it can be stated categorically that the range and size of local government expenditure assignments have been well clarified and have increased over time. Most of the countries are also heavily dependent on transfers from central governments to LGs. Of the five countries studied, Ghana has the most clearly institutionalised structures for facilitating such transfers - its constitution sets aside a proportion of the nation's revenues for district assemblies and this amount has increased from only 5 per cent to 7.5 per cent of the country's total income stream. There is also a clearly articulated formula for sharing among districts. Other countries have arrangements to provide recurrent and capital expenditures to LGs but this is not always transparent or predictable. In one case (Mozambique), the proportion of transfers has fallen from 3 per cent to 1 per cent. Internally generated revenue is consistently low in all countries. Few local governments have access to private borrowing among our five countries. It is particularly striking that data on local government finance remains scarce and unreliable across all five countries, as is evident from Table 7.4 and the other tables in this chapter.

Table 7.4. Degree of fiscal decentralisation

\begin{tabular}{|c|c|c|c|c|c|}
\hline Fiscal decentralisation & Botswana & Cameroon & Mozambique & Ghana & Tanzania \\
\hline $\begin{array}{l}\% \text { of national revenue } \\
\text { transferred to } L G\end{array}$ & Unknown & $\begin{array}{l}\text { Not } \\
\text { available }\end{array}$ & $1 \%$ & $7.5 \%$ & $27 \%$ \\
\hline $\begin{array}{l}\text { LG expenditure/state } \\
\text { government expenditure }\end{array}$ & Unknown & Unknown & 1 & Unknown & $22 \%$ \\
\hline $\begin{array}{l}\text { Formula-based sharing of } \\
\text { LG grants to LG }\end{array}$ & No & No & Yes & Yes & Yes \\
\hline $\begin{array}{l}\text { Presence of an independent } \\
\text { body that determines and } \\
\text { shares LG grants }\end{array}$ & No & No & No & Yes & No \\
\hline Local tax base & Low & Low & Low & Low & Low \\
\hline $\begin{array}{l}\text { Ability of LG to fix their own } \\
\text { revenue rate }\end{array}$ & Low & Low & Moderate & High & Moderate \\
\hline $\begin{array}{l}\text { LG internally generated } \\
\text { revenue relative to LG budget }\end{array}$ & $\begin{array}{l}\text { Less than } 20 \% \\
\text { urban councils } \\
3 \% \text { rural councils }\end{array}$ & Low & $7-15 \%$ & $5-40 \%$ & $10 \%$ \\
\hline $\begin{array}{l}\text { Clarity in expenditure } \\
\text { assignment }\end{array}$ & High & Low & Low & Moderate & High \\
\hline Autonomy for procurement & Low & Low & Moderate & Low & Low \\
\hline $\begin{array}{l}\text { Power to borrow from the } \\
\text { private sector }\end{array}$ & $\begin{array}{l}\text { Yes with } \\
\text { conditions }\end{array}$ & None & $\begin{array}{l}\text { Yes with } \\
\text { condition }\end{array}$ & Yes with & $\begin{array}{l}\text { Not clear } \\
\text { condition }\end{array}$ \\
\hline
\end{tabular}




\subsubsection{Human resource management at local level}

Normally, access to financial resources should boost the capacity of local level bodies to attract and retain high-quality local officials. In this report we assessed the human resource management capacity of local governance bodies using the following criteria: local institutional and staff capacity, and overall competence.

Local administrations and local governments in these five countries have substantial numbers of staff. Local governments in Botswana, for instance, have about 27,000 personnel representing 27 per cent of total government employment. Ghana's districts have 25 per cent of total government employees, while the figure rises to over 60 per cent of nearly 250,000 government personnel in Tanzania. Cameroon and Mozambique do not have a definitive figure but 85 per cent of all 172,000 Mozambican civil servants work at provincial and district levels as a part of the field administration. As is evident below, large numbers do not always mean that LG have officials with high-quality skills, but based on the available data LG capacity seems to have improved generally in most of the countries.

At independence district councils in Botswana had more responsibilities for human resource management. They were responsible for hiring schoolteachers, community development workers, sanitation officers and for basic management of their staff through an LG unified service (an arrangement that is half-way between human resources services that are 'centralised' in the national government and 'separated' for each local authority). However, the creation of the Department of LG Service Management (DLGSM) in central government took away the responsibility for human resource management (recruitment, transfer, training, and dismissal) from the district councils to ensure greater uniformity in conditions of employment across the country. Between 1991 and 2009, the number of people employed to work at the local level under local authorities has risen from 13,000 (representing 20 per cent of total government employment) to about 27,000 (27 per cent). The MoLG recruits all senior employees at the local level while the district councils were given the authority to recruit and manage all lower levels (mostly industrial workers and lower grade staff). On the whole human resource management procedures for local government staff have been centralised, even though LGs still play an important role in these processes as well.

It is noteworthy that the competence of employees at district councils has improved over the years. Many heads of departments in councils have university degrees while a few have postgraduate (masters) degrees. There have been both short- and long-term training programmes for local authorities, which have substantially improved their ability to provide the public services for which they are responsible. Although the centralised career structure for LGs is supposed to respond to the staff needs of remote districts through transfer and other personnel policies as well as create a basis for co-ordinated training and staff development programmes, its implementation 
raises some problems. LG's control of their employees is circumscribed and LG officials have an almost exclusive loyalty and accountability to the central government that employs them instead of the locally elected body. In addition, the centralised staff system delays decision-making regarding recruitment, dismissal, and disciplinary action at the local level.

In Mozambique Law 5/2006 was passed to decentralise 'human resource management' to provincial and district administration. Two sub-national organisations were given the authority to recruit, develop, promote, and dismiss their own employees. In 2007 the Ministry of Public Service was created with the mandate of ensuring that the public service was adequately resourced with human capacity and that civil servants who work in the various levels of state administration (central government, PG, DA and administrative posts) are properly regulated and managed (recruited, contracted, trained, promoted, dismissed, etc.). Law 5/2006, which regulates the recruitment and retirement of civil servants, was subsequently repealed by Law 14/2009. The capacity of the Mozambican civil service has improved over time but still remains low. However, those operating at the sub-provincial levels have extremely low levels of professional or academic qualifications. While in the mid-1990s, less than 2 per cent of the civil servants had a university degree (and most of whom were concentrated in the capital), data from the Ministry of State Administration shows that only 0.1 per cent of staff at the provincial level had a university degree, while 37 per cent had no formal education at all (UNCDF/UNDP, 1998). Although by 2008 there had been some improvements, generally human resource capacity at sub-national level has remained very low. The system of training in public administration (SIFAP) provides two types of professional training programme to remedy this shortfall. The first is the Higher Institute of Public Administration (ISAP) training programmes that are offered to central government employees, along with short courses for central, provincial and district administration staff. Pay levels generally tend to reflect the level of training. The monthly salary for new recruits with an elementary certificate is MT2,345 (US\$90.20); basic certificate MT3,283 (US\$126.30); medium general certificate, MT3,752 (US\$144.30), medium professional/technical certificate MT4,244 (US\$163.20), bachelor's degree MT5,980 (US\$230), and licenciatura (a four-year degree) MT7,715 (US\$296.70). It is noteworthy that the municipalities fix their own salaries, which need not be the same as the general civil service salary. For instance Maputo municipality pays competitive salaries that are higher than those paid by central government. A graduate with a licenciatura gets about US\$800 in Maputo while the central government only pays about US\$300. In Cameroon the Ministry of Public Service employs all civil servants except personnel of the army, police, judiciary, and prison administration. The size of the civil service is estimated at 160,000 workers. The exact number is not readily available because since 2007 the government embarked on a massive recruitment drive in the aftermath of a freeze in employment into the public service as a result of an economic crisis suffered two decades ago. Estimates of the total workforce at council level will not be available until early 2010. There has been no deliberate attempt to collate (or 
disseminate publicly) the national figure for local council staff. At an individual level, it is recognised that rich and poor councils have different abilities to engage and pay staff at local level. Recently, the minister in charge of public service ordered the setting up of a harmonised service structure for council employees - that is they will have a common staff organisation as well as a recommended minimum number of staff for each department under an LG. Ultimately this is to help set up a structure to learn staff numbers and get regular updates on staff variations and trends across all councils.

LGs in Ghana do not have their own employees. Almost all the technical staff or bureaucrats working in DAs are deconcentrated central government employees from sectoral ministries, agencies and departments. If there is one area in which implementation of Ghana's decentralisation has not worked, then it is the organisation and management of human resources. To deliver their responsibilities LG Act 462(38) requires LGs to establish departments (16 for a metropolitan assembly, 13 for a municipal assembly, and 11 for a district assembly) to deliver services to citizens. Financial support was not given to the DAs to hire personnel to fill these departments. The law therefore made provision for all 22 departments ${ }^{4}$ that were hitherto operating in LG jurisdictions as deconcentrated agencies of the central government to integrate their structures (staff, salary, function, budget, planning, etc.) into the DAs and become departments. But this did not happen as their parent sectoral ministries resisted this transfer, apparently because it would have taken away some of their powers, resources and influence. There were also legal issues to be rectified as some of the departments (for instance education and health services) were established by acts of parliament and needed similar legislative provisions to transfer them. LG Service Act 656 was enacted after 10 years thanks to donor pressure in December 2003, ostensibly to secure effective implementation of this integration. When the Act was finally passed in 2003 it only succeeded in transferring to LGs departments that were established through administrative procedures and not acts of parliament, so excluding local service departments like education and health, forestry, fire, and game and wildlife for which separate agencies had been created by central government. Employees of these departments constitute about 80 per cent of people working at the districts as deconcentrated sectoral staff. Even now, six years after the LG service law was passed, the transfer of about 33,000 out of 43,000 civil servants from the Office of the Head of Civil Service to LGs has not taken place because of legal contradictions. A legislative instrument to start the process has just been passed by parliament.

In essence, LGs in Ghana do not have functional or service delivery departments of their own, but work through deconcentrated central government departments and agencies and also through private-sector enterprises in the form of unstructured public-private partnerships. Deconcentrated government employees that work in collaboration with LGs to deliver services are appointed, posted, transferred, 
promoted, and disciplined by central government bureaucrats in Accra, who have little or no information about their work performance at the local level. Civil servants at the LG level have no allegiance to the DA in whose jurisdiction they work and they frequently ignore LG policies and priorities and generally maintain allegiance to the central government. Locally elected councillors face severe frustrations in the very LGs that they are supposed to control.

In Tanzania, LGs have appreciable levels of autonomy in human resources: that is, LGAs are expected to 'be fully responsible for planning, recruiting, rewarding, promoting, disciplining, developing and firing their personnel. The councils are the appointing authorities and employers for all LG personnel (including teachers, health staff, agricultural staff, etc.)' (GoT, 1998). LGAs 'employs the council director, the department heads, and will adopt staffing plans and budgets' (ibid.). Over 60 per cent of the 249,286 government employees are employed at the LGA level (URT, 2005). About 80 per cent of the workforce possesses at most a secondary education. As part of the D-by-D process, council staff are gradually being de-linked from their respective ministries. The head of the LG service is the district executive director in the district authorities and the town/municipal/city director in the urban authorities. Below the director are heads of department responsible for personnel and administration; planning and finance; engineering or works; education and culture; trade and economic affairs; urban planning; health and social welfare; co-operative, agriculture and livestock development; and community development. Table 7.5 summarises the state of HRM decentralisation in the five countries.

Table 7.5. Degree of human resources decentralisation

\begin{tabular}{llllll}
\hline Administrative decentralisation & Botswana & Cameroon & Mozambique & Ghana & Tanzania \\
\hline $\begin{array}{l}\text { Ratio of LG staff to total government } \\
\text { employees }\end{array}$ & $27 \%$ & Unknown & Unknown & & \\
$\begin{array}{l}\text { 85\% of central government in field } \\
\text { administration }\end{array}$ & $25 \%$ & $>60 \%$ & & & \\
$\begin{array}{l}\text { LG freedom to hire, Improving } \\
\text { motivate, train and fire LG staff? }\end{array}$ & Very limited & Low & Yes & Not yet & \\
$\begin{array}{l}\text { Freedom to contract out own } \\
\text { responsibilities }\end{array}$ & Yes & Unknown & Yes & Yes & Yes \\
\begin{tabular}{l} 
Capacity/competence of LG staff \\
\hline
\end{tabular} & Moderate & Low & Low & Low & Moderate \\
\hline
\end{tabular}

\subsubsection{Overall outputs: participation and service delivery}

As stated in chapter 1, the objectives of decentralisation are 'broader citizen involvement, empowerment and participation' and 'better service delivery'. In this section we review the available evidence from the five countries.

Overall it would seem that all of the countries have actually committed to a decentralisation policy with two main forms - deconcentration or field administration and 
devolution or local governments. In Botswana the long-term goals are highlighted in Vision 2016. At the district level, plans are prepared within the framework of the Vision 2016 and the National Development Plan (NDP). The planning process starts with the consultation process between the District Development Committee (DDC) and the Village Development Committee (VDC). The DDC, which is made up of deconcentrated sectoral officers at the district level, tells the community about government policies, programmes and priorities, while the VDC gives the DDC their shopping list of projects and priorities. All VDC projects are put together by the DDC under the co-ordinating leadership of the district commissioner and submitted to the district council for further prioritisation and decision-making. The key strength of the planning process is that it enables communities to 'dream' and 'think big'. However, in practice the planning process and subsequent budgeting have a number of weaknesses. While the planning process is complex and seeks to involve all stakeholders by using a bottom-up approach, the Ministry of Finance and Development Planning has the final say and normally resets priorities for districts without telling them why. Development planning in Botswana, despite the declared objective of 'bottom-up planning', continues to be top-down. Policies as well as the allocation of resources are determined at the central government level (Sharma, 2004). Local institutions criticise the planning process for not been participatory enough.

On the other hand, in terms of service delivery, Botswana's decentralisation has made a lot of progress. Batswana enjoy a very high standard of service provision in education, health, water and sanitation - more than most citizens in other African countries. The local councils have managed to effectively deliver basic services. The presence of deconcentrated sectoral agencies and departments, each with its own budget and employees, and the occasional direct implementation of projects at the local level by sectoral ministries, ensures that if one or more local institutions failed to function the other would somehow deliver, thereby ensuring not only expansion of services provision but also continuous delivery. Nevertheless the costs of providing services need to be analysed carefully in Botswana because the system appears to be too expensive to be adopted by any country that faces serious financial constraints

In 1998 Mozambique embarked on the decentralisation of state administration using two parallel processes: devolution of some central government functions, authority and finances to 43 municipal governments (mainly in urban areas), and administrative deconcentration by transferring specific duties and jurisdictions of the central government to 128 rural districts (called local bodies of the state) and providing them with the legitimacy and instruments to execute their tasks. The importance of decentralisation to Mozambique is further emphasised in the state's strategic vision 'Agenda 2025' and the government's ten-year Global Strategy for Public Sector Reform (2001-2011). These documents consider decentralisation as the most important pillar for modernisation of the state. 
Decentralisation is evident in the political, fiscal, administrative and accountability reforms that have taken place in the country in terms of the relationships between the centre, provinces, districts and municipalities. The development that has taken place since 1998 constitutes significant progress in Mozambique, given the country's historical, economic, socio-cultural, political, and institutional background.

An important achievement of decentralisation in Mozambique is the expansion of services delivery, although systematic data is patchy. Anecdotal evidence suggests that the provision of basic services has improved in rural areas as a result of a massive injection of government funds to district administrations (DAs). The proportion of the population with access to potable water has increased from 37.1 per cent (2001) to 48.5 per cent (2007). In terms of basic sanitation, in 2007 25,638 pit latrines were built in rural areas all over the country, which represents 39 per cent coverage (GoM, 2008: 12). In the urban areas there has been an improvement in solid waste collection and land-use planning. The coverage for urban water supply has also risen, from 31.2 per cent in 2000 to 40 per cent in 2007. The government official report on the assessment of the Millennium Development Goals (MDGs) clearly points out that there is potential to halve the number of people without access to safe drinking water and sanitation. Primary school completion rate has significantly increased from 38.7 per cent in 2003 to 72.6 per cent in 2007. The construction of classrooms and recruitment of teachers were considered key issues for achieving this. There has been progress in these services partly because they have been decentralised to district administrations and provincial governments instead of being provided by the central government as in the past.

Another achievement of decentralisation in Mozambique is the gradual improvement of voter turnout at municipal elections. While voter turnout in national elections is falling steeply (from 87 per cent in 1994 to 44 per cent in 2009), in local elections it is rising substantially (from 15 per cent in 1998 to 46 per cent in 2008). This suggests that people are beginning to see the relevance of local democracy while they feel indifferent to the national level. With a gradual increase in the number of municipalities, local democracy will improve further to cover wider Mozambican society and not only the few urban areas. In addition Mozambique is among the few countries in Africa where mayors and councillors are directly elected by the people through universal adult suffrage. Mozambican municipal administration has a clear separation of powers between the local legislative assembly and the executives.

For Cameroon, for most of her history and until recently ministries have been the key service deliverers. Every ministry uses a hierarchy of field offices to deliver services in sub-national units. Thus, representatives of sector ministries based in the councils handle most aspects of service provision. From 2010, council mayors have been charged with additional responsibilities for service delivery based on a phased transfer of jurisdictions from sector ministries. 
Information obtained from sampled councils show a remarkable increase in funds accruing to them. In some councils, like Limbe City Council, revenue to the city council's coffers saw an almost ten-fold increase in the five-year period from 2004 to 2008. Revenue available to councils in the form of taxation is governed by Law 2002/003. Councils are permitted to collect tax from local businesses that do not generate more than CFAfr 100,000; businesses that generate more than this amount are taxed under the jurisdiction of the central government.

The real challenge is that it has taken 14 years since the initial constitutional declaration of decentralisation for the first real transfer of responsibilities and resources to councils to take place. This unusually long period has created negative signals that there is some reluctance on the part of central governments to strengthen LGs. The legal instrument itself is not sufficient to effectively accelerate the pace of the decentralisation process. But Cameroon's unique dichotomous colonial identity, which has influenced the structure of the post-colonial state, as well as the complex heterogeneous ethnic structure, deserves sensitive management.

Ghana's decentralisation policy has ensured that more people now have access to LG administration, thereby shrinking the distance between the citizens and their government. The mandatory transfer of not less than 7.5 per cent of the central government revenue to LGs has helped not only to improve the financial state of LGs (without which many would have collapsed) but also ensured that district capitals became new growth poles that helped spread development across the length and breadth of the country. The District Assemblies Common Fund (DACF) has helped to improve infrastructure in rural areas more than any local development intervention ever implemented in the country. Nevertheless Ghana's decentralisation also faces a lot of implementation challenges. Arguably the most challenging issue is how to bridge the gap between the constitutional and policy intentions of decentralisation and the actual practices.

Tanzania introduced a decentralisation policy as a reaction to earlier programmes of deconcentration. Its Local Government Reform Programme (LGRP) was introduced in stages: the first stage was a 10-year period that lasted from 1999 to 2008; the second stage started in 2009 and will end in 2014. The country made its policy preference for devolutionary decentralisation clear, hence the concept of decentralisation by devolution. Major findings indicate that in the first stage political decentralisation has entrenched a system of regular elections for ward councillors, village councils, mtaa committees and kitongoji chairs every five years. In addition one-third of local posts are set aside specially for women and other marginalised groups; council meetings are now open to the public, resulting in improvements in agenda-setting and reporting of meetings; and council's powers have expanded to include drafting byelaws covering areas such as community development, waste collection and sanitation, and local revenue generation. When Rungwe District Council privatised the collection of market fees it increased revenues by 83 per cent per annum. 
One-third of all positions in local government councils are reserved for women. This is regarded as a positive development for several reasons. First, it boosts the participation of a group that is usually marginalised. Second, it also ensures that the group with the greatest interest in local matters - basic health (especially maternal and child health), basic education, water and sanitation, youths and sports, etc., has the greatest say in these matters. It is thus not surprising that service provision has improved in the Tanzanian education sector. Each ward is now supposed to have one secondary school, but some wards now have more than one. More than 75 per cent of children are in primary school, and more than 50 per cent of them go on to secondary school (a ward is about five villages; each village has approximately 250 households, constituting 1,500 people). In the health sector, service provision has been decentralised to district level. Each ward now has health centres and there are dispensaries in nearly every village, but their impact on improvements in major health indicators is not easy to assess. Also in each district, there is space set aside to build hospitals. Private participation in health service delivery is on the rise, especially from faith-based organisations such as the Catholic and Lutheran Church (these Christian institutions run referral hospitals in Mwanza and Kilimanjaro regions). LGAs have also improved in terms of organisational structure, construction of markets, and garbage collection - in collaboration with the private sector (pers.comm., Secretary General, ALAT).

\subsection{Lessons and Challenges}

This last section draws together the different strands of facts and findings on these five country cases. We shall focus on the main lessons, challenges and possible intervention points.

\subsubsection{The lessons and challenges}

The research started with a number of specific propositions. In the review contained in the earlier parts of this chapter, we have attempted to revisit these propositions in the light of our findings. The propositions led us to draw a map, as it were, of the progress of decentralisation as well as the challenges confronting decentralisation in Africa. There was also an attempt to understand the differences between the formal policy and actual practice of decentralisation in each country, and especially the role of state and non-state actors in this process. Two important key actors that were singled out for special consideration were government actors and donors who have been critical in setting the agenda on decentralisation in many African countries.

We now proceed to focus on some recurring themes across all five countries and provide an insight into the dynamics of initiating and sustaining decentralisation in the African context. 
Eight major recurring themes emanate from the analysis of these case studies on African decentralisation experiences. These are summarised below:

(a) Importance of context - geographic, political, economic and historic

(b) Close links between democratisation and decentralisation

(c) Conceptual and policy ambivalence and confusion in respect of decentralisation

(d) Governance of cities and rural communities

(e) Primacy of politics in the analysis of the sustenance of decentralisation reforms

(f) Role of donors vis-à-vis other national actors

(g) Inadequate emphasis on the human and financial resources options

(h) Weak links to new institutional actors involved in local governance

(a) Importance of context - geographic, historic, political and economic: Context plays an important role in terms of the type, quality, approach and progress of decentralisation. This helps to explain the diverse approaches to decentralisation in all of these countries. For instance, the slow progress of decentralisation in Cameroon may be attributable to several reasons but one unmistakable issue is the difficult co-existence of two traditions of decentralisation within the same political system in a country that is now unitary though it was once federal. Tanzania, another country that was once federal, has now switched to a unitary system of government even though the system of (local) governance differs between the mainland and the island of Zanzibar. Physical and demographic size is also an issue. For large territories such as Tanzania and Mozambique, decentralisation is essential for the realisation of state policies and programmes. However, even for a relatively small country like Botswana, decentralisation has been a key part of the state's strategy to realise that country's development plans and especially Vision 2016. It is significant that all five countries have a history in which decentralisation has been regarded as an important principle of governance and political independence since colonial times, despite the diverse rhetoric on approaches to development (whether state-directed as in Tanzania and Mozambique or market-directed as in Cameroon, Ghana and Botswana).

The differences arise from different historical trajectories such as war, as in Mozambique, long adherence to strong socialist principles, as in Tanzania, or the legacy of long years of military rule, as in Ghana. These experiences complicated the emergence and continue to hamper the progress of decentralisation in different ways in these countries. A pattern that is found in all five countries is the tendency for the development strategy implementation to neglect rural communities. Decentralisation is thus seen as a state strategy to tilt the balance in favour of rural communities, 
but as the examples of Mozambique and Botswana show, economic success does not always translate into progress for rural communities. For instance, in Mozambique consistent high economic growth rates over a decade have not had a positive impact on the rural areas; this is because the major investments have concentrated on mega projects financed by direct foreign investment in minerals (e.g. the MOZAL aluminium project or the SASOL gas pipeline to South Africa) while the agricultural sector, which offers economic opportunities and employment for 80.5 per cent of the population, received only 3.3 per cent of public investment. Similarly, Botswana's impressive economic performance still leaves large numbers behind in the rural communities. Effective decentralisation strategies that recognise local communities as economic entities (devolution) are required to correct these imbalances between the rural and urban economies within the same country. There are also wide differences in experiences and the implementation of decentralisation in mainland Tanzania in contrast to Zanzibar or the English-speaking and French-speaking parts of Cameroon. Economic prosperity may seem to make it easier for the state to embark on ambitious decentralisation programmes successfully (Botswana) while poverty remains a continuing challenge for the others.

In summary, war, natural disasters, historical affinities, urban and rural divides as well as economic strategies have implications for decentralisation - indeed it may form the rationale for policy choice with significant policy impacts as well.

(b) Close links between democratisation and decentralisation: Another recurring theme is that whereas all the countries had some experience of decentralisation before the era of democracy, the preferred policy choice in the years before democratisation was deconcentration. With the emergence of what has been referred to as the global democratic third wave (Huntington, 1993) associated with the fall of the Berlin wall in 1989, decentralisation programmes took on a completely new character, different from preceding types. This movement was propelled in Africa by domestic as well as external forces as is evident from the five countries reviewed in this study (Hyden et al., 2000). The Tanzanian leadership, for instance, actually abolished local governments on 30 June 1972 in favour of the socialist field administration agencies flowing from the party's philosophy of socialist centralisation (democratic centralism) or ujaama. This 'decentralisation reform', meant grouping villages together and administering them as a part of one central state using the government's appointed consultative forums in the districts and villages - hence the reference to villagisation. One important lesson from this experience was that service delivery did not improve; if anything, it degenerated. Ten years later, in 1982, this ban on local government was lifted, first in the urban areas and then in the rest of the country.

Subsequent activities in that country have sought to enhance the democratic character of decentralisation with varying levels of success. A similar, almost dramatic story was captured in the chapter on Cameroon: the opposition had sent a formal request to the United Nations for independence for Southern (English-speaking) Cameroon from 
the rest of the nation before the government passed decentralisation legislation that promised local autonomy and devolution. In the same vein, the Mozambican war was one that expressed itself in terms of control by the main parties - the ruling FRELIMO and the opposition RENAMO, each of whom had power in a different part of the country, the ruling party in the cities and the opposition in the countryside. Some observers felt that it is therefore not surprising that until now devolution had been having a hard time in Cameroon generally and in the other two countries (Botswana and Mozambique) outside the cities (see below). It is clearly impossible to dissociate the ongoing efforts to engage decentralisation from the prevailing democratisation agenda in each of the five countries. Indeed, in some of the countries, notably in Cameroon, Ghana and Mozambique, decentralisation was a concession granted to appease a growing and restive opposition to unitary, one-party rule that dominated the political and policy space from independence to the 1990s.

(c) Conceptual and policy ambivalence and confusion in respect of decentralisation: The first two points also provide an explanation for the policy and deliberate ambivalence of many countries in respect of devolution and deconcentration. With the exception of Tanzania, there seems to be a consistent preference to implement deconcentration, even though the formal policies are in favour of devolution. This ambivalence is unfortunate. First, it does not allow the countries to come up with a robust policy for effective field administration as distinct from local governments. Both are needed, and indeed if effectively done one could strengthen the other. Second, some of the countries that have attempted to make a policy distinction between deconcentration (in the rural areas) and devolution (in the cities) such as Mozambique - and lately Cameroon - have not provided a clear sense of how their respective countries would transit from one type of decentralisation to another over time. Clearly, there is a need to articulate within these countries' decentralisation policies a time-based plan on when and how to transit from one form of decentralisation (deconcentration) to another (devolution) or indeed whether there would not be a need for such transformation at all.

Another important recurring theme is the tendency for the countries not to follow through on their policy commitments in respect of decentralisation. Whereas in December 1995 the Cameroon National Assembly approved a new constitution that legalised political parties, adopted multiparty democracy and 'declared Cameroon decentralised and heralded steps for actualising decentralisation', and President Biya signed this into law in January 1996, not much happened until 2004. Even now, real actions to promote devolution are to be put in place only from 2010. This means that it has taken eight years to implement the deconcentration aspects of the reform and another six years (assuming it happens) to implement devolution. Even the Tanzanian case provides a curious approach to decentralised (devolutionary) governance in that the country started in 1999 as a part of the country's democratisation and economic liberalisation programme. This programme is significant in 
that it was supported by a number of donor agencies. Initially, some 38 councils were selected randomly from among urban and rural areas that would form the start-up councils. The idea was that other councils would join them on a progressive basis, as in neighbouring Uganda. In 2004, however, all the councils joined this local government development programme. In addition, the programme was now to go beyond districts to the village councils as well. Such discontinuities might indeed be necessitated by new facts, but the lack of a systematic pursuit of policy objectives also has high costs, as was highlighted in the report.

The Ghana case further illustrates this challenge in a graphic way. Regional ministers exercise a great influence on the policy and processes of the district assemblies that are supposed to be semi-autonomous in their operation. Indeed, the district chief executives serve as the leader or mayors of their district assemblies while elected officials serve as presidents, and as we saw these district assemblies do not manage their own staff. In all the countries, the instruments for promoting devolution - e.g. the revenue transfers, human resources support and indeed the audit processes and systems - have become veritable instruments for ensuring a deconcentrated decentralised system even when this is contrary to policy pronouncements on the subject.

In sum, at the heart of the dilemma confronting many countries in Africa is the need to clarify what kind of decentralisation they are interested in pursuing. The history of decentralisation in the continent shows that most central government actors would like to enhance the capacity of their respective field administrations. However, the citizens and donor agencies push for devolution. Could it be that central government actors want what guarantees a hold on power whereas citizens and donors would like those who wield power to tap the immense local or domestic human, financial and knowledge resources resident in communities? Both power and resources are essential for the effective and efficient functioning of the state. In this circumstance and encouraged by donor agencies, some central governments pursue a policy of decentralisation when in fact their preference is fundamentally for deconcentration, not devolution. The result is a mixture of different forms of devolution and deconcentration that is at times reflected in policy implementation inconsistencies.

(d) Governance of cities and rural communities: Despite their possible reservations, decentralisation has a strong appeal to policy-makers in that it provides them with a tool or an approach that can help to harmonise the differences between the various groups that comprise a society. It can help ensure some form of horizontal integration across communities that comprise a nation. Moreover, it can also bring about vertical integration between national and local governments. In addition, as earlier highlighted, decentralisation is a tool for promoting the political objectives of democratisation but it is also a tool for achieving the economic liberalisation objectives of longer term development planning. Some countries, like Botswana and Mozambique, have resolved this problem by adopting an official policy that promotes devolution in the cities while continuing with deconcentration in the rural areas since 
these areas are not regarded as sufficiently ripe for devolution. The two countries that have not fully articulated this kind of policy in our sample countries are Tanzania and Ghana, although both might have actually pursued it while implementing their decentralisation policies. Based on the available evidence, Ghanaian cities have been able to mobilise far more financial resources than their rural counterparts. Internally generated revenue accounts for 11 per cent in Tamale, 32 per cent in Kumasi and 44 per cent in Accra. This compares with the average of 5 per cent for the rural districts in the Upper Eastern, Upper Western and Northern Regions of that country.

The logic of urban devolution and rural deconcentration is an attractive one. It responds to the following realities:

- Urban communities are able to raise the finances for providing and supporting services in a way that many rural communities cannot.

- Urban inhabitants are more demanding of their political leaders and more participative than rural inhabitants in the governance of their communities.

- Urban communities have become increasingly important in the era of globalisation, as many multinational companies have relocated away from their headquarters in the search for more markets and cheaper production costs.

The problem is that the countries in our sample have not carried this policy logic to its conclusion. They have tended to spend most of their transfers on the cities (with or without formal financial transfer formulas) and not on the rural communities that need grant transfers most. In addition, they have not encouraged these cities - some of them are quite big and have considerable economic and financial clout to mobilise much higher internally generated resources, especially taxes and fees on movable (like vehicles) and immovable properties (real estate). The reason these cities cannot do this includes the lack of legal empowerment by the national government to enable them to determine their own tax rates or even their local budget. This is inconsistent with the principles of devolution. It is even more important to do this because African cities in the past were actually able not only to mobilise resources but also run services, including ports and city transportation, and some of them were even active in international stock exchanges across the world (Olowu, 2004). Several municipal governments in the Commonwealth are still able to do this in part because of their robust internally generated revenues regime, including some in Africa such as Mauritius and the Republic of South Africa (Commonwealth Local Government Forum, 2006).

(e) Primacy of politics in the analysis of the sustenance of decentralisation reforms: Most analysis of decentralisation takes a partial rather than a comprehensive view. For instance, some focus only on how to initiate decentralisation reforms and not on how to sustain them. Some others discuss the importance of technical capacity at the level of local governments but not at the national government level. Even more 
importantly, some analysts focus on political aspects of decentralisation because they tend to be neglected by most analysts. In this book we have adopted a holistic focus. That approach led us to significant insights on the dynamics of sustaining decentralisation once it has been introduced.

The analysis shows that the capacity for initiating decentralisation is just as important as the capacity for sustaining it. Whereas most analysts and political commentators focus on the lack of technical capacity at the local level to sustain devolution, what emerges from our analysis is that both technical and political capacities are required, and these are needed at both national and local levels. Indeed, the need for technical and political capacity is more crucial at national or central government level than at the local level for the following reasons:

- Until a national government appreciates that decentralisation can help it to achieve a positive-sum (win-win) game, it will continue to perceive it as a zero-sum game in which local actors gain what it loses. They thus try to avoid or impede it despite of national policy commitments.

- Decentralisation is a complex process and requires both political sophistication and administrative dexterity at the national and local levels. There is often considerable opposition to decentralisation within national governments, especially because there are different kinds of actors and interests.

- Donors are showing a growing interest in decentralisation for a variety of reasons. They bring resources, experience and expertise to this field. However, central governments are needed to mediate the relationships between local communities and external actors in all countries.

- Only when a national government is genuinely interested in devolving authority, responsibility and resources will there be a need to improve local government capacity.

- Improving local government capacity is a long, tedious and often frustrating experience that requires time, patience, understanding and a willingness to allow some initial failures as part of any learning process.

For all of these to happen, political capacity or willingness is actually more important than technical capacity because where there is political capacity, technical capacity will follow. It is therefore important to focus on the dynamics of political capacity for initiating and sustaining decentralisation generally but especially devolutionary decentralisation.

Three types of stakeholders are particularly crucial in introducing and sustaining decentralisation. These are national state political actors, senior administrative or management officials of the state, and local community actors (see Table 7.6). 
Table 7.6. Analytical framework for sustaining decentralisation (model)

\begin{tabular}{|c|c|c|c|}
\hline & National political elites & National administrative elites & Local political elites \\
\hline Initiating & High & & \\
\hline Implementing & & High & \\
\hline Sustaining & & & High \\
\hline \multicolumn{4}{|l|}{ Botswana } \\
\hline Initiating & High & & \\
\hline Implementing & & Moderate & \\
\hline Sustaining & & & Low \\
\hline \multicolumn{4}{|l|}{ Cameroon } \\
\hline Initiating & Low & & \\
\hline Implementing & & Low & \\
\hline Sustaining & & & Moderate \\
\hline \multicolumn{4}{|l|}{ Ghana } \\
\hline Initiating & Low & & \\
\hline Implementing & & Moderate & \\
\hline Sustaining & & & Moderate \\
\hline \multicolumn{4}{|l|}{ Mozambique } \\
\hline Initiating & Moderate & & \\
\hline Implementing & & Low & \\
\hline Sustaining & & & Low \\
\hline \multicolumn{4}{|l|}{ Tanzania } \\
\hline Initiating & Moderate & & \\
\hline Implementing & & Moderate & \\
\hline Sustaining & & & Low \\
\hline
\end{tabular}

Introducing devolution is primarily a political function but so is its sustenance. If the forces that helped to introduce it do not continue to support it or are no longer in a place to influence policy, devolution suffers reversals, leading to what is referred to as recentralisation. This phenomenon has been encountered in some of our five countries. Table 7.6 summarises some of the major observed trends.

In Botswana, the forces that brought about a review of devolution legislation were formidable, as they included the country's president. Devolution was connected to three key national programmes: development planning, a principle that Botswana has pursued with vigour over the years when many countries jettisoned theirs (now upgraded to National Vision 2016), rural development, and the reform of the public sector. The administrators have not always been so enthusiastic about devolution and have therefore continued to use the argument that local government capacity is weak as a basis for recentralising functions when in fact the capacity of local government in this country has improved and the quality of performance of local governments 
has not been observably worse than national government. This was also because the country uses standards of performance measurement.

The problem in Botswana, of course, is that the local political elite forces have weakened over time, a fact responsible for the sudden loss of major cities by the opposition to the national ruling party in elections.

The pattern in other countries is predictable. National forces in favour of devolution are weak in Cameroon but moderate (especially significant has been the role of development partners) in the other two countries, Mozambique and Tanzania. Local political elites are also weak in both countries, but the administrative elite in Tanzania is stronger in terms of its commitment to devolution than those in Mozambique, given the lessons they learnt in the 1970s when local councils were abolished. In Mozambique the most important point is that the administrative elite in the cities, especially in Maputo, are well-motivated and better paid than national government workers. Ghana illustrates how the role of external donors can force the hand of the national government in promoting devolutionary decentralisation as they made the enactment of the local government service act a condition for continuing donor support.

In sum, once the political capacity for sustaining decentralisation in a country is high, it will be reflected in the systematic development of technical capacity at national and local levels. Hence, the prevailing refrain that is often heard about capacity deficiency in decentralised agencies is actually a reflection of the lack of political will in support of decentralisation nationally and in particular at the national level. Where sufficient political will exists, technical capacity deficiencies can be remedied over time using a combination of policies and strategies to attract and retain quality staff members into decentralised agencies. This has been found to work in all countries. It is, therefore, not surprising that even in countries where there has been tremendous improvement in the quality of local government staff, such as in Botswana and Tanzania, national reports still show that their central governments use the weak capacity in local governments as the rationale for transferring responsibilities and financial resources to other institutional actors controlled directly by the national government. This happens despite the fact that these local councils have done well in terms of delivering services and mobilising ever greater numbers of people to vote even as citizens' participation in national elections decline.

(f) Role of donors vis-à-vis other national actors: For a variety of reasons, donors are interested in supporting decentralisation reforms. First, as we saw in the opening chapter, they believe that progress in decentralisation would have a favourable impact on the attainment of the MDGs. Second, they also see decentralisation reform as an important aspect of good governance reforms that cover both political and economic liberalisation. Finally, decentralisation is good politics for these donors both from the viewpoint of macro-national politics and international influence but also for 
micro-political reasons not unconnected with the fact that some of their multinational companies are active in specific communities in these countries, e.g. in mineral or agricultural extraction. In a sense, there is evidence coming from these reports that progress in devolutionary decentralisation has led to marked and remarkable improvements in basic services - in basic health and education in Botswana, health in Mozambique and in basic education in Tanzania. Clearly, decentralisation and especially devolution reforms that bring greater autonomy in the operations of national and local governments result in higher standards of services delivery and this is not lost on these donors who would like to have something positive to show to their own domestic taxpayers. ${ }^{5}$

The country cases, especially Tanzania, Ghana and Mozambique, underscore other important contributions that external actors (donors) bring to the progress of devolution. They bring political clout and huge resources that promote decentralisation. These resources are mostly financial but not exclusively so. They bring to bear their expertise, other international knowledge and experience, and they also support capacity building even at district and village levels, as we saw in Tanzania. On the downside, it is the case that even when these resources have not been used to actually promote devolution by the national governments, they cannot openly challenge the government. In Cameroon, the government was able to turn away from the German donor GTZ that was pushing for devolution and do business with the French co-operation agency that seemed to be less insistent on imminent progress. Even in Tanzania, the report shows that the co-chair of the development partners group was dissatisfied that little or no advance had been made in respect of human resource development. Indeed, the government seems to have pulled the local governments back - they curbed their power 'to hire and fire' and emoluments of council staff were still being handled centrally after almost 12 years of devolution.

This is not to underestimate the great progress that decentralisation has made in Tanzania. It is significant that these development partners have pushed the idea of budget support and that it has been applied almost exclusively to national governments and also to local governments. All the development partners supporting decentralisation in Tanzania, for instance, place their funds in a basket fund, which explains the great progress made by that country as the country report showed. On the whole, it is fair to say that donors can only exert substantial muscle where they harmonise their support to the country and where such support is substantial, as the Ghana case shows.

A meeting of experts at the European Commission (EC) in October 2009 underscored the point that support for devolutionary decentralisation might become the most important single element for improving domestic accountability in recipient countries, as the EC has been placing more development resources in this area. In other words, donors may be hoping that they can help boost development performance and 
especially domestic accountability in recipient countries by taking the following key measures related to fiscal decentralisation reforms. These are:

- promote local and national government's own-resource mobilisation and promote discretionary funds to local governments within EC response strategies and policy dialogue;

- develop performance-based funding to establish effective incentives and competition for de-concentrated and decentralised levels to improve performance in terms of equity and transparency; and

- consider larger public administration reforms in tandem with policy dialogue on decentralisation. (European Union, 2009).

An important development arising from donor involvement has also been the effective engagement of non-government actors, such as faith-based organisations, philanthropic institutions and community-based groups, and especially the national local government associations in the dialogue on governance and accountability improvement. This has impacted positively on the quantity and quality of services delivered in virtually all five countries.

(g) Inadequate emphasis on the human and financial resources options: The five countries studied have not given sufficient attention to human and financial resources options. Taking finance first, two of the countries (Tanzania and Ghana) have clearly articulated transfer and grant systems that show the factors taken into consideration in calculating central government transfers to local governments. But even here, the country reports note that financial transfers from the centre are still problematic; all local governments continue to depend on the national government and LG discretionary authority hardly exists in either of the two countries.

But the experience is still far better than for the other three countries where there is no transparent formula for sharing that is known to all the parties - central government, local government and non-governmental actors at the community level. The Tanzania report also notes that even Angola, a country that has just emerged from war and which began its decentralisation programme quite recently, has made more effective use of the financial transfers formula to stimulate greater dynamism for local development in their revenue drive. It is also instructive that the Ghanaian government has increased the level of central government transfers from 5 per cent to 7.5 per cent, whereas in Mozambique the proportion has been reduced by half - from 3 per cent to 1.5 per cent. In Cameroon, local entities collect monies and send them to the capital, and from there the amounts sent to councils are sent at the national government's discretion, with no council knowing exactly how much it might receive!

There is much less discussion of and achievement in mobilising human resources. One of the best cases of the lot, Botswana has actually moved away from a model that is 
more favourable to local autonomy (the local government service commission) that is independent of both the central and local governments. The same goes for Cameroon and Ghana. The two countries that have non-centralised options are Tanzania and Mozambique, the latter only in respect of her municipalities. They set and manage their own staff conditions. It is significant that, for instance, the Municipality of Maputo actually has more attractive service conditions than the central government and its field administration units in the provinces and districts. Even within field administration systems (deconcentration), these five governments are yet to come up with conditions of service that provides special incentives that respond to the problems of working in rural communities where there are no basic services. In the absence of any such incentives it is the norm to see high absenteeism, poor service provision by such personnel and, in extreme cases, departure and flight to other organisations or even other countries (Clemmens, 2007).

The facts show that the human resource capacity of local governments have actually improved over time and this shows in their increasing ability to successfully deliver services either alone (as in Botswana and Tanzania), in collaboration with national government field agencies (as in Mozambique and Cameroon) or with private agencies (as in Ghana). Yet, national governments are reluctant to recognise this maturing on the part of local governments in their countries or even accord them greater discretionary authority in managing local government human resources.

(h) Weak links to new institutional actors involved in local governance: One of the most important positive developments of decentralisation reforms in all five countries is that it has brought new actors into local-level development. For instance, three of the countries have provided greater opportunities for women's involvement in local politics and development; three countries have a quota for women (Ghana, Mozambique and Tanzania) and in one of these (Tanzania) women outperformed men in local elections. In Tanzania, one study showed that the local electorate trusted their religious leaders and institutions more than their members of parliament (Tidemand and Msani, 2008). A variety of institutions are now involved in local governance: local for-profit and non-profit organisations, local government associations and other civic and community-based organisations, including faith-based organisations. Unfortunately, these organisations are still left out of the policy discourse on decentralised governance even though they have demonstrated an extra ordinary capacity to network, partner and co-produce with decentralised agencies of government.

For any organisation to be effective in attracting human co-operation, it must provide essential institutional incentives that tackle issues of collective action, collective decision-making, principal agent and constitutional choice challenges (Ostrom, 1996, Wunsch, 2009). Collective action problems arise when an organisation has too limited an authority to tackle real issues and there is a lack of homogeneity among the actors. Collective decision-making challenges happen when organisations are too weak to make decisions on areas of their competence, and so let others make decisions. Principal 
agent problems happen when the electorate cannot effectively hold the leaders of decentralised bodies/authorities responsible for their actions or inactions. The constitutional choice challenges relate to the inability of these local organisations to design or redesign themselves in light of their experiences.

Neglect or inadequate attention to the above issues may actually define what is often referred to as the weak capacity of decentralised bodies. The challenge might be that there are no effective policy interventions (policies and strategies) from the central government that respond to the problems. This is the focus of Section 7.4.2. However, before going into this we highlight some significant good practices across all five countries that other nations might want to consider for further study and adoption.

\subsection{Good Practices and Potential Interventions}

\subsubsection{Highlights of good practices}

In this section, we highlight practices that are considered good and worthy of further study and possible emulation by other countries in the region. These include:

Clear articulation of policy choice: A number of countries have had decentralisation programmes that formed the basis for a number of government actions but no decentralisation policies. Even when there is a decentralisation policy, no clear distinction was made in terms of policy focus between deconcentration and decentralisation. The Tanzania decentralisation by devolution policy was different and formed the basis of more robust policy guidance for the many actors involved in formulating, implementing and evaluating different aspects of decentralisation policy in that country. It is not an accident that the Tanzanian decentralisation programme is one of the most outstanding in terms of the policy outputs of participation and services delivery.

Learning from past experiences: As earlier noted, decentralisation is an old issue in all the countries studied. However, the knowledge acquired over the years in implementing various aspects of decentralisation is not always clearly connected to new initiatives. Most countries had experimented for several years with deconcentration; for example Ghana and Cameroon and had seen the high costs in terms of negative development, services delivery and participation. Yet, their decentralisation policies and programmes are still ambivalent. Again this is one area where the Tanzanian case has been different. The essence of the new policy of decentralisation is to make a clean break with the mistakes of the past. The country's first president has said that his decision to scrap local governments in the 1970s was one of his greatest policy errors. His successors made up their minds not to repeat such an error. Hence there is a more nuanced policy of preference for devolutionary decentralisation in their current initiative. 
Decentralisation co-ordination agency: An understanding of the multidisciplinary nature of decentralisation suggests that it is wise to have a central co-ordination agency with political and technical clout to guide, persuade, implement and co-ordinate the decentralisation policy implementation. Every reform is resisted by those who believe that they will lose from the new initiative. Hence, there is a need for a central co-ordination agency to ensure that the policy process is not blocked by reluctant ministers or senior administrators. The existence of such a body in Tanzania, Ghana and Cameroon has helped in various ways.

Separation of urban and rural governance in policy and practice: Regrettably decentralisation reforms in many countries do not make a distinction between urban and rural areas. This review suggests that the differences between urban and rural are so substantial that the countries that recognised these differences in their policy and practice (especially Mozambique) seem to have had a better handle on implementing their decentralisation programmes. However, it is not sufficient to only make a policy distinction, it is important as well to make clear the path of convergence over time, otherwise such a policy might be counterproductive both politically and economically.

Constitutional protection for local governments: This is a commendable practice in that it raises the legal status of local authorities and ensures that national governments could not easily erode the powers of local authorities. The experience of Ghana shows that this can go a long way to assist the development of LGs in an environment in which the senior officials resist devolution reforms, as it relates to the transfer of personnel from national to local authorities. This is further enhanced by another good practice.

Mandatory central transfers to local authorities: This has resulted in the effective transfer of resources to LGs, and in the two countries in which it has been practiced - Ghana and Tanzania - it has led to substantial improvements in service delivery. It contrasts with what has happened in the other countries in this study. For example, in Mozambique the national government reduced central transfers unilaterally from 3 per cent to 1.5 per cent and actually paid only 1 per cent in 2009. In Botswana, the amount that is transferred varies annually and there is no way that the LGs can predict how much they will receive. This makes planning extremely difficult, as central transfers constitute the largest source of revenue for LGs worldwide. The flip side is that LGs can become excessively dependent on this source and be lax in mobilising their own revenues. The situation might also undermine effective accountability.

Enhanced capacity of local government chief executive: Most local government chief executives find the weak mayor system that they inherited from the colonial period a serious challenge, as it makes it difficult for them to effectively co-ordinate the work of the councillors or of the supporting heads of departments. Mayors under this system are elected by the councillors, who also oversee the council via a committee system. To 
this extent, many of them prefer the strong mayor system, where the chief executive is popularly elected and has executive powers that are exercised at political and administrative levels. Only Mozambique has introduced this kind of innovation in its municipalities and the model is viewed favourably by most countries. The 2 nd Presidential Commission on Decentralisation in Botswana recommended the adoption of strong or executive mayors. The government declined, but some people (within and outside the government) are still pushing for this system. Nigerian LGs use this system and recently Kenyans have chosen this model as a part of the country's constitutional reform proposals (Kenya Parliamentary Select Committee, 2010).

Human resource management for effective decentralised governance: It is important that human resource management (HRM) for decentralised governance is distinct from the national government. Only a few countries have been able to separate national and local HRM. Mozambique uses the separate personnel management model in its cities and each city has its own HRM system. Botswana and Tanzania use a local government service management model, which seeks to protect professionals from political victimisation while separating the system from the national government. It also ensures that small localities have access to quality professional leadership.

There are two other HRM initiatives that are also important to highlight. The first is the introduction of performance management at the local government level. Botswana has done this well, making it mandatory for all systems, national and local, to comply with performance management indicators. This has had a positive impact on the quality of services delivered in that country by LGs as well as other agencies of governance. The second is training for local government officials. Tanzania sets aside a proportion of its personnel budget for training and this is commendable.

Quotas for women: One-third of all positions in local government are reserved for women in Tanzania. This has led to some positive developments in participation and the quality of services delivered. The Ghanaian quotas have not been very well managed, unfortunately. On the other hand, women are regarded as a part of the effort to reach out to minorities who are co-opted into the district assemblies.

Inclusion of traditional chiefs in local government: Different countries in our sample have adopted different approaches to traditional chiefs. Tanzania banned these chiefs altogether in the days of socialism. Botswana has recognised chiefs as separate decentralised actors charged with specific duties outside of the formal local government system. Ghana has integrated them into the formal local government system by appointing some of them to district and regional assemblies. Each country must determine what the best way is to make use of traditional chiefs, who continue to be important in African cities and villages. 


\subsubsection{Potential interventions and ways forward}

Besides the specific good practices, in this final section we discuss some broader policy interventions that could help to tackle some of the challenges confronting decentralised governance in the countries that we have reviewed.

We explore here potential joint actions or entry points by these countries in collaboration with the Commonwealth Secretariat, who sponsored this study. In particular, the following five main proposals have been identified as core and possibly catalytic:

Improve the capacity of national governments to support and sustain decentralisation through learning from their own past experiences and from the available literature on local organisations.

- Use central transfers to mobilise potential domestic financial resources.

- Explore alternative human resource management possibilities other than central government control.

- Reconcile central-led planning to decentralisation.

- Use external assistance to improve policy dialogue on decentralisation and domestic accountability and include more local organisations in monitoring and discussing the progress of decentralisation.

Improve the capacity of national governments to support and sustain decentralisation: We made the point that decentralisation is a complex venture. A critical issue is building the capacity of central governments by using available knowledge in this important area. All five countries were carrying out decentralisation reforms even before they became politically independent, and have continued since. It would seem critical that they learn from these experiences. Unfortunately, this has not always been the case. Central governments still use the same language, emphasising the superiority of national versus local governments or even deconcentration compared to devolution, when in fact this is not the issue. Both national and local governments are essential, as are devolution and deconcentration in any country. More importantly, what is often missing is an understanding of how to create the incentives for institutional effectiveness at both national and local levels, whether within field administrations or semi-autonomous local governments. One line of research that recently attracted global attention with the award of the 2009 Nobel Prize in economics is the need to understand collective action, principal-agent and constitutional choice principles in the creation and management of central and local government bodies and their agencies as identified earlier (see Ostrom, 1996 and Wunsch, 2009). This is the only way to explain why local and philanthropic organisations have often succeeded where much better resourced, government-supported organisations fail.

Helping national governments to improve knowledge management in decentralisation programmes is an important area that can be addressed through networks, 
communication (using both old and new technologies), and enhancing the capacity of regional- and national-level training institutions to impart such knowledge.

Use central transfers to leverage potential domestic financial resources: There is a need to deliberately use central transfers to incentivise the mobilisation of financial resources, especially in cities. For example, two important revenue sources that have been poorly tapped in all five countries are property taxes and user charges, including parking fees. The technology and processes for assessing and collecting these fees are well known and it should not be difficult to document the experiences of other countries (even within Africa) that have been able to raise huge resources from these sources. The key issue, however, is that this is not only about money; it is also about developing effective domestic accountability for the local capital market. This was a critical issue for the construction of modern societies in today's developed world. Property markets provided a basis for responsible democracy, service management, and the enhanced capacity of local governments to borrow and indeed develop their property markets (Kersting et al., 2009). Similar arguments could be made for other potential local revenue sources that are presently poorly exploited (Bahl and Linn, 1992). The idea would then be that central transfers and grants would focus not only on population and equity, as is currently the case, but also on revenue mobilisation potential and actual performance.

Explore other human resource management (HRM) options: HRM has become part of strategic management, and it is important that the policy discourse and practice on this issue be changed in Africa. Africa is losing a lot of human resources to foreign countries when in fact its major challenge remains the lack of critical human resources capacity in many areas. The problem is the poor conditions under which people are required to serve; these conditions are neither competitive nor reflect the reality of the challenges that service providers at the local level face in these countries. The fact that national and external governments have increasingly realised the importance of decentralised bodies in this area should help to change the policy discourse in terms not only of conditions of service, but also of human resource management models: centrally controlled, separate, market controlled, local government commissions and co-operative arrangements. It is instructive, for instance, that in Mozambique municipalities have the freedom to hire their own personnel on terms that are more generous than the national government. This is the way it should be, as cities can also easily raise the revenue that would enable them to attract and retain critical skills.

Reconcile central-led planning to decentralisation: As most countries have now returned to national planning, mostly via poverty reduction strategies and national visioning processes, the relationship between development planning and decentralisation remains unclear. There is still a strong need to enhance central government field administration, local governments and other local governance bodies (non-governmental agencies, community-based organisations, local government associations, faith-based groups, etc.) to create an effective national framework for development 
planning. Where countries do not have a clearly articulated policy that links development planning to decentralisation, it might be necessary to help countries to establish these links.

Use external actors to improve policy dialogue on decentralisation: It has become increasingly evident that development partners are playing a critical role in Africa's development management. As noted earlier, the portfolio of these institutions has grown phenomenally. In some cases, the resources made available by these organisations constitute the main elements of capital or development budgets, whether at national or local levels. The key point, however, is that these resources and the donors' political clout can be used to support the mobilisation of financial and human resources, but also to leverage a higher quality of domestic accountability. They would achieve these by leveraging a wider spectrum of actors within African countries, especially including the local governing bodies.

In conclusion, the five countries analysed here have all undertaken decentralisation reforms that aimed to promote improved governance and effective service delivery. These twin objectives have been partly achieved in most of the countries. Decentralisation policy implementation is a work in progress that needs deepening. It is also important for the countries to look inward and mobilise domestic resources to support and sustain decentralisation and other related governance reforms.

As examples of African decentralisation, these case studies provide insights into why decentralisation has not been as successful here as it has been in other regions of the world. Lessons from these experiences underscore the fact that decentralisation is advanced by the following actions:

- Constitutional protection and a clear articulated sense of responsibility assigned to local authorities, as distinct from field administration agencies.

- Clear financial and human resources provision to match the level of decentralised responsibilities.

- Reconciliation of development planning to devolution to semi-autonomous regional and local authorities.

- Mobilisation of domestic resources not only in terms of finance but also of human, knowledge and institutional resources to complement and ultimately replace external inputs.

- Empowerment of citizens and local councils to contract, co-operate and compete with other governance bodies in the public and private realms to boost local development and local good governance.

This project has the unique opportunity to move policy discourse and practice on decentralisation in Africa to a new level in which national and local institutions complement one another in improving development and governance. Crucially, 
follow-up actions on this report could focus on three key targets that could revolutionise African governance and poverty alleviation successes that have proved rather elusive to date. First, it could become the nucleus of an effort to build a consistent and reliable database on African decentralisation that could be regularly updated to improve policy and the twin objectives of decentralisation: popular empowerment and effective service delivery. Second, it could target a redynamisation of African governance, starting with the cities. As Africa experiences its triple revolutions demographic, capitalist and electronic - effort focused on dramatically democratising the governance ${ }^{6}$ of her exploding cities might provide the much-needed push to improve the welfare of millions of Africans living in mankind's continent of origin. Third, it can task national resource centres in each country to work with the key actors in-country to revitalise municipal devolution while enabling national governments to support such efforts. This would have positive implications for the whole country, in that it would release to rural communities the much-needed government grants presently tied up in sustaining deconcentration even in the cities.

\section{Notes}

1. For instance, Ronald Wraith wrote a book called Local Government in West Africa (1964), but when he published a second edition in 1972, the title had changed decisively to Local Administration in West Africa (1975).

2. Central and local elections are organised at the same time but we were not able to lay hands on local election turnout specifically. Some other data that we had access to showed that turn out at national elections fell from 70.1 per cent in 1999 to 56 per cent in 2003 (Kuenzi and Lambright, 2007). The figures that appear here may therefore be for local elections.

3. Fifteen per cent of the total fund is deducted or reserved by the common fund administrator before the remainder $(85 \%)$ is distributed to the DAs. So 15 per cent is not part of the five factor formula.

4. Departments of Social Welfare; Community Development; Town and Country Planning; Public Works; Parks and Gardens; Rural Housing and Cottage Industry; Births and Deaths; Forestry; Controller and Accountant-General; Medical Officer of Health; Feeder Roads; Animal Health and Production; Fisheries; Extension Services; Crop Services; Agricultural Engineering; Districts Sports; Cooperatives; Fire Services; Library Boards; Game and Wildlife; and National Youth and Organizing Commission.

5. There is a lot of concern presently that donor assistance, especially in poor countries, does not work and only aggravates rather than ameliorates poverty (see Moyo, 2010).

6. Over 30 per cent of Africans live in cities, up from 15 per cent in 1965. The number will rise to 50 per cent in another 10 years. See Kapstein, 2009: 119-128. 